\title{
ANALYSIS OF PATIENTS WITH SPINAL CORD TRAUMA ASSOCIATED WITH TRAUMATIC BRAIN INJURY
}

\author{
ANÁLISE DE PACIENTES COM TRAUMA RAQUIMEDULAR ASSOCIADO A TRAUMATISMO \\ CRANIOENCEFÁLICO
}

\section{ANÁLISIS DE LOS PACIENTES CON TRAUMATISMOS VERTEBRALES ASOCIADOS CON TRAUMATISMOS ENCEFÁLICOS}

João Simão de Melo Neto ${ }^{1}$, Waldir Antônio Tognola ${ }^{1,2}$, Antonio Ronaldo Spotti², Dionei Freitas de Morais 1 ,2

\begin{abstract}
Objective: Characterize victims of spinal cord injury (SCI) associated with traumatic brain injury (TBI) and risk factors. Methods: Study conducted with 52 victims of SCl associated with TBI. The variables studied were: sex; age; marital status; occupation; educational level; religion; etiology and the lesion area; neurological condition by the ASIA scale; associated injuries and potential risk factors. Results: The male (85\%), aged between 21-30 years (25\%), civil status stable union (56\%), low level of education (69\%) and the Roman Catholic religion (77\%) presented the greater number of victims. Motor vehicle accidents (58\%) were the main etiology. The cervical segment had higher injury risk (RR=3.48, $p<0.0001)$. The neurological status ASIA-E (52\%), the syndromic neck pain (35\%) and the rate of mild TBI (65\%) were the most frequent. Complications occurred in 13 patients with increased frequency of pneumonia (62\%). The length of hospital stay was significantly higher (20 \pm 28 days) and $17 \%$ of patients died. Men $(R R=2.14, p=0.028)$ and individuals exposed to motor vehicle accidents $(R R=1.91, p=0.022)$ showed a higher risk of these lesions concurrently. Moreover, these patients had $2.48(p<0.01)$ higher risk of death than victims of SCl alone. Conclusion: The $\mathrm{SCl}$ associated with TBI was more frequent in men, young adults, and individuals exposed to motor vehicle accidents. The cervical spine is more likely to be affected. Furthermore, the length of hospitalization is significantly higher and the subjects analyzed have higher risk of death.
\end{abstract}

Keywords: Spinal Injuries; Craniocerebral trauma; Epidemiology.

\section{RESUMO}

Objetivo: Caracterizar vítimas de trauma raquimedular (TRM) associado a traumatismo cranioencefálico (TCE) e fatores de risco. Métodos: Estudo realizado com 52 vítimas de TRM associado a TCE. Foram estudadas as variáveis: sexo; idade; estado civil; profissão; escolaridade; religião; etiologia e região do TRM; condição neurológica pela escala da ASIA; lesões associadas e fatores de risco em potencial. Resultados: O sexo masculino (85\%), a faixa etária entre 21-30 anos (25\%), o estado civil de união estável (56\%), o baixo nível de escolaridade (69\%) e a religião Católica Apostólica Romana (77\%) apresentaram um maior número de vítimas. O acidente automobilístico (58\%) foi a principal etiologia. O segmento cervical teve maior risco de lesão (RR=3,48; $p<0,0001)$. O estado neurológico ASIA-E (52\%), o quadro sindrômico de cervicalgia (35\%) e o índice de TCE leve (65\%) foram os mais frequentes. As complicações atingiram 13 pacientes, sendo pneumonia a de maior frequência (62\%). O tempo de internação foi significativamente maior (20 \pm 28 dias), e 17\% dos pacientes foram a óbito. Os homens $(R R=2,14 ; p=0,028)$ e indivíduos expostos a acidentes com veículo automotor $(R R=1,91 ; p=0,022)$ apresentaram maior risco de sofrer essas lesões concomitantemente. Além disso, esses pacientes apresentaram 2,48 ( $p<0,01)$ mais risco de morte que vítimas de TRM isolado. Conclusões: O TRM associado ao TCE foi mais frequente em homens, adultos jovens, além de indivíduos expostos a acidentes com veículo automotor. A coluna cervical tem mais risco de ser afetada. Além disso, o tempo de internação é significativamente maior e os indivíduos analisados apresentaram mais risco de óbito.

Descritores: Traumatismos da coluna vertebral; Traumatismos craniocerebrais; Epidemiologia.

\section{RESUMEN}

Objetivo: Caracterizar las víctimas de traumatismos vertebrales (TV) asociados con traumatismos encefálicos (TE) y los factores de riesgo. Métodos: Estudio realizado con 52 víctimas de TV asociados con TE. Se estudiaron las siguientes variables: sexo; edad; estado civil; profesión; educación; religión; etiología y el área de la lesión; condición neurológica por la escala ASIA; lesiones asociadas y factores de riesgo potenciales. Resultados: El varón (85\%), con edades comprendidas entre 21-30 años (25\%), estado civil de relación estable (56\%), bajo nivel de educación (69\%) y la religión católica (77\%) presentaron un mayor número de víctimas. Los accidentes de tráfico (58\%) fueron la principal etiología. El segmento cervical presentó mayor riesgo de lesión ( $R R=3,48, p<0,0001)$. El estado neurológico ASIA-E (52\%), cuadro sindrómico de dolor del cuello (35\%) y la tasa de TE leve (65\%) fueron las más frecuentes. Las complicaciones ocurrieron en 13 pacientes, con una mayor frecuencia de la neumonía (62\%). La estancia hospitalaria fue significativamente mayor (20 \pm 28 días) y el $17 \%$ de los pacientes murió. Los hombres $(R R=2,14, p=0,028)$ y los individuos expuestos a accidentes de tráfico $(R R=1,91, p=0,022)$ mostraron un mayor riesgo de estas lesiones en forma concomitante. Además, estos pacientes tenían 2,48 ( $p<0,01)$ mayor riesgo de muerte que las víctimas del TV aislado. Conclusión: El TV asociado con el TE fue más frecuente en los hombres, los adultos jóvenes y las personas expuestas a los accidentes de vehículos automotores. La columna cervical es más propensa a ser afectada. Además, la estancia en el hospital es significativamente más larga y los individuos analizados presentaron un mayor riesgo de muerte.

Descriptores: Traumatismos vertebrales; Traumatismos craneocerebrales; Epidemiología.

1. Faculdade de Medicina de São José do Rio Preto (FAMERP), São José do Rio Preto, SP, Brazil

2. Hospital de Base, São José do Rio Preto, SP, Brazil.

Study conducted at the Hospital de Base de São José do Rio Preto, São José do Rio Preto, SP, Brazil.

Correspondence: Dionei Freitas Morais: Av. José Munia, 4850 - Jardim do Sul. 15090-500. São José do Rio Preto, SP, Brasil. dionei@ cerebroecoluna.com.br 


\section{INTRODUCTION}

Spinal cord injury (SCl) is an injury to the soft and bone tissues of the vertebral column and spinal cord that results in permanent or temporary sequelae in the sensory, autonomic and motor functions. ${ }^{1}$ Traumatic brain injury (TBI) results in psychological, social and physical deficits, such as sensorimotor, emotional, language and cognitive impairment, and consequently, deterioration of functional capacity and quality of life. ${ }^{2} \mathrm{SCl}$ and $\mathrm{TBI}$ are among the primary causes of global morbimortality, ${ }^{3,4}$ but if these injuries occur in association, the victim is expected to have a worse prognosis. At the present time, failures have been observed in the diagnosis of these associated injuries during admission to post-traumatic rehabilitation. ${ }^{5}$

There are few studies ${ }^{6-8}$ involving victims of TBI associated with $\mathrm{SCl}$, and those that exist have varied methodologies. Moreover, the precise risk factors have not been described in detail. ${ }^{7}$ Health professionals expect the literature to offer evidence-based practice; however, when dealing with these associated diagnoses, there is no solid scientific basis, which hinders the practice of these professionals. ${ }^{9}$ Therefore, new surveys are necessary to achieve better characterization, diagnosis, advances in evaluation techniques and adequate treatment.

Accordingly, this study aims to characterize patients who are victims of spinal cord injury associated with traumatic brain injury, as well as the possible risk factors.

\section{METHOD}

A descriptive, prospective cross-sectional study held at the tertiary reference center, Hospital de Base de São José do Rio Preto, SP, Brazil. Three hundred and twenty-one patients were preselected with a diagnosis of SCl in the period from January 2008 to June 2012. The criterion for inclusion was TBI as an injury associated with $\mathrm{SCl}$. Both diagnoses were confirmed by means of initial clinical and radiological evaluation.

During the clinical evaluation, the following observations were made: altered levels of consciousness; reports of accentuated pain or symptoms of spinal cord injury with accentuation of these conditions in orthostatism; autonomic dysfunctions, such as priapism, alterations in fecal and urinary continence; and multiple lesions. The patients underwent radiological confirmation using computed tomography and/or magnetic resonance.

The characterization of the patients was based on the following variables: gender; age; marital status; level of education; religion; occupation; etiology, morphology and $\mathrm{SCl}$ region; neurological status of the patients using the ASIA scale; ${ }^{1}$ set of symptoms; level of TBI; associated injuries; complications; treatment; length of hospitalization and deaths.

The TBI level was rated using the Glasgow coma scale (GCS), according to the score obtained in the clinical evaluation, as mild (GCS: 13-15), moderate (GCS: 9-12), or severe (GCS: 3-8).

The regions of the injury in the patients with $\mathrm{SCl}$ were: upper cervical (C0-C2), lower cervical (C3-C7), thoracic (T1-T10), thoracolumbar transition (T11-L2), and lumbosacral (L3-S1). ${ }^{9}$

Descriptive and inferential statistics were used for the data analysis. The descriptive results were expressed in mean, standard deviation $( \pm)$, absolute and relative frequencies. The following tests were used: Mann-Whitney to compare average length of hospitalization; and the relative risk (RR) between the variables with Fisher's exact test. A significance level of $p \leq 0.05$ was considered. The statistical analysis was performed in the Instat program (version 3.0; GraphPad, Inc., San Diego, CA, USA).

This study was approved by the Research Ethics Committee of the Faculdade de Medicina de Rio Preto, SP, Brazil. FAMERP, protocol No. 4823/2009.

\section{RESULTS}

Of the 321 individuals with SCI, 52 patients (85\% male) who presented with associated TBI were studied. The average age was $38.6( \pm 19.2)$ years. In the evaluation of age distribution, it was noted that the most predominant age group was $21-30$ years in $25 \%$ of the patients. (Table 1 )
The most frequent marital status was common-law marriage in $56 \%$ of the sample, the most predominant level of education was incomplete primary education (69\%), and Roman Catholicism (77\%) was the religion of the highest number of victims. (Table 1) Occupations were general helper/housekeeper (12\%), student $(12 \%)$, bricklayer $(10 \%)$, driver $(8 \%)$, cattle rancher $(6 \%)$, painter (6\%), and other occupations (46\%).

Car accident (58\%) was the most frequent etiology of $\mathrm{SCl}$ associated with TBI. The main morphologies of $\mathrm{SCl}$ were fracture and dislocation (23\%) and fracture of posterior elements (23\%), while eight patients presented two associated injuries, totaling 60 morphologies. The lower cervical spine (C3-C7) was the segment most often affected in $58 \%$ of the patients, and four patients suffered injury in two segments, totaling 56 regions affected. (Table 2)

The neurological status assessed by the ASIA ${ }^{1}$ scale was " $A$ " in $15 \%$, "B/C/D" in $21 \%$, and "E" in $52 \%$, while six patients were in a prolonged coma (GCS < 8), preventing the evaluation of this parameter.

The set of syndromes consisted of neck pain (35\%), tetraparesis $(15 \%)$, back pain (13\%), tetraplegia $(10 \%)$, paraplegia $(6 \%)$, neck pain with paresthesia (6\%), paraparesis (4\%), and $11 \%$ were in a coma. As regards the TBI level, about $65 \%$ of the patients presented with mild trauma, while $27 \%$ had severe and $8 \%$ moderate trauma.

Table 1. Frequency distribution of age group, marital status, level of education and religion of the 52 patients with spinal cord injury associated with traumatic brain injury.

\begin{tabular}{|c|c|c|}
\hline & Frequency & $(\%)$ \\
\hline \multicolumn{3}{|l|}{ Age group } \\
\hline $0-20$ years & 08 & $15.5 \%$ \\
\hline $21-30$ years & 13 & $25 \%$ \\
\hline $31-40$ years & 08 & $15.5 \%$ \\
\hline $41-50$ years & 08 & $15.5 \%$ \\
\hline $51-60$ years & 08 & $15.5 \%$ \\
\hline$>61$ years & 07 & $13 \%$ \\
\hline \multicolumn{3}{|l|}{ Marital status } \\
\hline Single & 29 & $56 \%$ \\
\hline $\begin{array}{c}\text { Married or Common-law mar- } \\
\text { riage }\end{array}$ & 21 & $40 \%$ \\
\hline Widow/widower & 01 & $2 \%$ \\
\hline Divorced & 01 & $2 \%$ \\
\hline \multicolumn{3}{|l|}{ Level of education } \\
\hline Incomplete primary education & 36 & $69 \%$ \\
\hline Complete primary education & 06 & $11 \%$ \\
\hline $\begin{array}{c}\text { Incomplete high school educa- } \\
\text { tion }\end{array}$ & 05 & $10 \%$ \\
\hline Complete high school education & 01 & $2 \%$ \\
\hline Higher education & 04 & $8 \%$ \\
\hline \multicolumn{3}{|l|}{ Religion } \\
\hline Roman Catholic & 40 & $77 \%$ \\
\hline Protestant & 06 & $11 \%$ \\
\hline Other or not stated & 06 & $12 \%$ \\
\hline
\end{tabular}


Table 2. Frequency distribution of etiology, morphology and segment affected of the 52 patients with spinal cord injury associated with traumatic brain injury.

\begin{tabular}{|c|c|c|}
\hline & Frequency & $(\%)$ \\
\hline \multicolumn{3}{|l|}{ Etiology } \\
\hline Car accident & 30 & $58 \%$ \\
\hline Motorcycle accident & 07 & $13 \%$ \\
\hline Fall & 06 & $11 \%$ \\
\hline Dive into shallow water & 05 & $10 \%$ \\
\hline Sport & 03 & $6 \%$ \\
\hline Firearm wound & 01 & $2 \%$ \\
\hline \multicolumn{3}{|l|}{ Morphology } \\
\hline Fracture-dislocation & 12 & $23 \%$ \\
\hline Posterior element fracture & 12 & $23 \%$ \\
\hline Listhesis & 10 & $19 \%$ \\
\hline Crush fracture & 09 & $17 \%$ \\
\hline Spinal cord contusion & 04 & $8 \%$ \\
\hline Burst fracture & 04 & $8 \%$ \\
\hline Odontoid fracture & 04 & $8 \%$ \\
\hline Other & 05 & $10 \%$ \\
\hline \multicolumn{3}{|l|}{ Segment } \\
\hline Upper cervical (C1-C2) & 11 & $20 \%$ \\
\hline Lower cervical (C3-C7) & 30 & $54 \%$ \\
\hline Thoracic (T1-T10) & 10 & $18 \%$ \\
\hline $\begin{array}{c}\text { Thoracolumbar transition } \\
\text { (T11-L2) }\end{array}$ & 05 & $9 \%$ \\
\hline
\end{tabular}

Only 27 patients suffered a total of 39 injuries associated with the accident, the most frequent of which was facial trauma in $33 \%$ of these patients, while $41 \%$ of the patients presented with two, and $4 \%$ with three associated injuries (Table 3). Complications affected 13 patients, of which about $62 \%$ evolved to pneumonia, and eleven patients presented with two or more, totaling 24 complications. (Table 3 )

The patients were submitted to conservative treatment $(50 \%)$ and surgical treatment (50\%); the average hospitalization time was $20 \pm 28$ days, and $17 \%$ of the patients died.

We noted that men $(R R=2.14 ; p=0.028)$ have a higher risk of suffering these associated injuries than women. The cervical segment $(R R=3.48 ; p<0.0001)$ had a greater risk of being the affected region. Moreover, car accident victims are 1.69 times more likely to suffer $\mathrm{SCl}$ associated with TBI $(p=0.043)$, and this rate is accentuated when it comes to any accident involving a motor vehicle $(R R=1.91$; $\mathrm{p}=0.022$ ). The individuals who suffered $\mathrm{SCl}$ associated with TBI had significantly longer $(p=0.011)$ hospitalization times than those who suffered $\mathrm{SCl}$ alone ( $9 \pm 12$ days). In addition, these patients presented a $2.48(p<0.01)$ times high risk of death than victims of $\mathrm{SCl}$ alone.

\section{DISCUSSION}

When SCl occurs concomitantly with $\mathrm{TBI}$, it may result in increased morbidity, impair quality of life, and hinder the rehabilitation process. ${ }^{6}$ In this context, the purpose of this study was to characterize these individuals and analyze the potential risk factors.

In this survey, we observed that men had a greater risk than wo-
Table 3. Frequency distribution of associated injuries and complications of the 52 patients with spinal cord injury associated with traumatic brain injury.

\begin{tabular}{c|c|c}
\hline & Frequency & (\%) \\
\hline Associated injury & & \\
\hline Facial trauma & 09 & $24 \%$ \\
\hline Injuries to upper limbs & 07 & $18 \%$ \\
\hline Thoracic trauma & 06 & $15 \%$ \\
\hline Fractures of lower limbs & 05 & $13 \%$ \\
\hline Hip fracture & 03 & $8 \%$ \\
\hline Rib fractures & 03 & $8 \%$ \\
\hline Other & 06 & $14 \%$ \\
\hline Complications & & \\
\hline Pneumonia & 08 & $33 \%$ \\
\hline Urinary tract infection & 04 & $17 \%$ \\
\hline Sepsis & 02 & $83 \%$ \\
\hline Respiratory failure & 02 & \\
\hline Other & 08 & \\
\hline
\end{tabular}

men of suffering these associated injuries, especially young adults (21-30 years of age). Morais et al. ${ }^{3}$ state that the $\mathrm{SCl}$ in this population may be prevalent at a global level. Vasconcelos and Ribeiro ${ }^{10}$ add that SCI victims have a greater prevalence due to their challenging behavior, with more involvement in high-risk activities. Moreover, common-law marriage was the most common marital status, and studies ${ }^{3,11}$ relate it to age and higher exposure to accidents. The level of education and religion found can be attributed to socioeconomic and political differences. ${ }^{11}$

Our study enabled us to ascertain that traffic accidents increase the risk of suffering $\mathrm{TBI}$ in victims of $\mathrm{SCl}$, as observed in other studies. $^{10,12}$ The surveys ${ }^{3,13}$ relate this cause of $\mathrm{SCl}$ to the more developed and urbanized geographical regions. Furthermore, other factors that can influence these results are reckless driving and poor road signs. Investments in raising awareness of the importance of traffic laws and the use of safety equipment are vitally important. ${ }^{12}$

Mild TBI and ASIA-E were the most frequent neurological statuses on admission. The ASIA scale associated with diagnostic imaging tests collaborate for better monitoring, treatment, and follow-up, besides playing a crucial role during admission, as they contribute towards a better prognosis of victims of isolated SCl. ${ }^{14-16}$

In the individuals with $\mathrm{SCl}$ associated with $\mathrm{TBI}$, we noted that the cervical segment was the region with the greatest risk of injury; that pneumonia was the main complication; and that these patients had an increased risk of death. TBI is the most common severe associated injury in victims of $\mathrm{SCl}$ with injuries in the cervical segment. ${ }^{17}$ Other surveys ${ }^{8,17}$ found the same association. This segment is crucial for the innervation of the respiratory muscles from the peripheral nerves. ${ }^{9}$ Thus, following injury to the cervical spine, the victim becomes more susceptible to respiratory complications such as pneumonia, increasing the risk of mortality. ${ }^{9,18}$ These results were also found in this survey.

The individuals studied had significantly greater hospitalization times. This fact can be explained by the cognitive, neurobehavioral and motor alterations resulting from TBI, which hinder rehabilitation. The motor alterations that can be found include coordination and postural control deficits. Therefore, the value of investments in the rehabilitation process should be stressed for these patients. ${ }^{19}$ 


\section{CONCLUSION}

Spinal cord injury associated with traumatic brain injury was more common in young adults in a common-law marriage and with a low educational level. Pneumonia was the main clinical complication. Men and individuals exposed to accidents involving a motor vehicle were at a greater risk of suffering these injuries concomitantly.
The cervical spine is more likely to be affected. Furthermore, the hospitalization time is significantly longer, and these individuals have a higher risk of death.

All authors declare no potential conflict of interest concerning this article.

\section{REFERENCES}

1. Morais DF, de Melo Neto JS, Spotti AR, Meguins LC, Mussi SE, Tognola WA. Image diagnosis of patients submitted to spinal injury. J Bras Neurocirurg. 2013;24(1):33-9.

2. Hegde S. Music-based cognitive remediation therapy for patients with traumatic brain injury. Front Neurol. 2014;5:34

3. Morais DF, Spotti AR, Cohen MI, Mussi SE, de Melo Neto JS, Tognola WA. Epidemiological profile of patients suffering from cord spinal injury treated in tertiary hospital. Coluna/ Columna. 2013;12(2):149-52.

4. Morais DF, Spotti AR, Tognola WA, Gaia FFP, Andrade AF. Clinical application of magnetic resonance in acute traumatic brain injury. Arq. Neuropsiquiatr. 2008:66(1):53-8.

5. Sharma B, Bradbury C, Mikulis D, Green R. Missed diagnosis of traumatic brain injury in patients with traumatic spinal cord injury. J Rehabil Med. 2014;46(4):370-3.

6. Hagen EM, Eide GE, Rekand T, Gilhus NE, Gronning M. Traumatic spinal cord injury and concomitant brain injury: a cohort study. Acta Neurol Scand Suppl. 2010;(190):51-7.

7. 7. Macciocchi S, Seel RT, Thompson N, Byams R, Bowman B. Spinal cord injury and co-occurring traumatic brain injury: assessment and incidence. Arch Phys Med Rehabil. 2008;89(7):1350-7.

8. Cook N. Respiratory care in spinal cord injury with associated traumatic brain injury: bridging the gap in critical care nursing interventions. Intensive Crit Care Nurs. 2003:19(3):143-53.

9. Harris P. Associated injuries in traumatic paraplegia and tetraplegia. Paraplegia 1968:5(4):215-20.

10. Vasconcelos EC, Ribeiro M. Caracterização clínica e das situações de fratura da coluna vertebral no município de Ribeirão Preto, propostas para um programa de prevenção do trauma raquimedular. Coluna/Columna. 2011;10(1):40-3

11. lida H, Tachibana S, Kitahara T, Horiike S, Ohwada T, Fujii K. Association of head trauma with cervical spine injury, spinal cord injury, or both. J Trauma. 1999:46(3):450-2.

12. Davidoff G, Thomas P, Johnson M, Berent S, Dijkers M, Doljanac R. Closed head injury in acute traumatic spinal cord injury: incidence and risk factors. Arch Phys Med Rehabil. 1988;69(10):869-72.

13. Feng HY, Ning GZ, Feng SQ, Yu TQ, Zhou HX. Epidemiological profile of 239 traumatic spinal cord injury cases over a period of 12 year in Tianjin, China. J Spinal Cord Med. 2011:34(4):388-94.

14. Leal-Filho MB, Borges G, Almeida BR, Aguiar AAX, Vieira MACS, Dantas KS, et al. Epidemiologycal study of 386 cases with emphasis on those patients admitted more than four hours after the trauma. Arq Neuropsiquiatr. 2008;66(2-B):365-8.

15. DeVivo MJ. Epidemiology of traumatic spinal cord injury: trends and future implications. Spinal Cord. 2012;50(5):365-72.

16. Bradbury CL, Wodchis WP, Mikulis DJ, Pano EG, Hitzig SL, McGillivray CF, Ahmad FN, Craven $\mathrm{BC}$, Green RE. Traumatic brain injury in patients with traumatic spinal cord injury: clinical and economic consequences. Arch Phys Med Rehabil. 2008;89(Suppl 12):S77-84.

17. Morais DF, de Melo Neto JS, Meguins LC, Mussi SE, Filho JR, Tognola WA. Clinical applicability of magnetic resonance imaging in acute spinal cord trauma. Eur Spine J. 2014;23(7):1457-63.

18. Wilson JR, Grossman RG, Frankowski RF, Kiss A, Davis AM, Kulkarni AV, et al. A clinical prediction model for long-term flectional outcome after traumatic spinal cord injury based on acute clinical and imaging factors. J Neurotrauma. 2012;29(13):2263-71.

19. Cheran S, Shanmuganathan K, Zhuo J, Mirvis SE, Aarabi B, Alexander MT, et al. Correlation of MR diffusion tensor imaging parameters with Asia motor scores in hemorrhagic and nonhemorrhagic acute spinal cord injury. J Neurotrauma. 2011;28(9):1881-92. 